Home | Archives | About | Login | Submissions | Notify | Contact | Search

ES HOME > VOL. 5, NO. 2 > ART. 14

Copyright (c) 2001 by the author(s). Published here under license by The Resilience Alliance.

The following is the established format for referencing this article:

Saxena, K. G., K. S. Rao, K. K. Sen, R. K. Maikhuri, and R. L. Semwal. 2001. Integrated natural resource management: approaches and lessons from the Himalaya. Conservation Ecology 5(2): 14. [online] URL: http://www.consecol.org/vol5/iss2/art14/

A version of this article in which text, figures, tables, and appendices are separate files may be found by following this link.

Insight, part of Special Feature on Integrated Natural Resource Management

\title{
Integrated Natural Resource Management: Approaches and Lessons from the Himalaya
}

K. G. Saxena ${ }^{1}$, K. S. Rao ${ }^{2}$, K. K. Sen ${ }^{2}$, R. K. Maikhuri ${ }^{2}$, and R. L. Semwal ${ }^{1}$

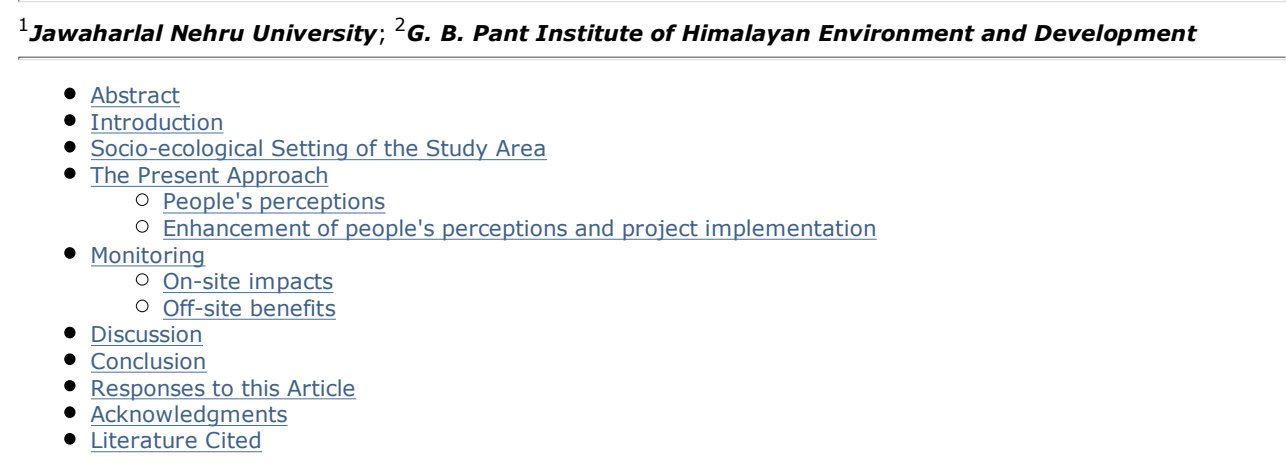

\section{ABSTRACT}

Losses of forest cover, biodiversity, agricultural productivity, and ecosystem services in the Himalayan mountain region are interlinked problems and threats to the sustainable livelihoods of $115 \times 10^{6}$ mountain people as well as the inhabitants of the adjoining Indo-gangetic plains. Until the 1970s, environmental conservation, food security, and rural economic development were treated as independent sectors. The poor outcomes of sector-oriented approaches catalyzed efforts to address environmental and socioeconomic problems concurrently. The identification of "key" natural resource management interventions is an important dimension of integrated management. Projects to rehabilitate the degraded lands that cover $40 \%$ of the Indian Himalaya could be key interventions provided that they address both socioeconomic and environmental concerns across spatial and temporal scales. However, projects of this type, e.g., investments in conifer plantations on degraded forest lands, have failed because their designs did not take into account the needs of local residents. This study illustrates a case of land rehabilitation in a small isolated village close to the alpine zone. Vital elements of this project strategy included identifying local perceptions and knowledge and involving the local people in the selection and implementation of the interventions needed to restore the land. Communities were found to be more concerned with the immediate economic benefits from bamboo and medicinal species than the long-term benefits of tree planting. The villagers eventually reached a consensus to plant broadleaved multipurpose trees in association with bamboo and medicinal species. Despite assurances that all the economic benefits from rehabilitation would go to the community, the people would not agree to voluntary labor, although they did absorb significant costs by providing social fencing, farmyard manure, and propagules from community forests. Households shared costs and benefits according to traditional norms. The economic benefits to the local people exceeded the rehabilitation cost over the 7-yr life of the project. There were significant on-site environmental benefits in terms of improvements in soil fertility, biodiversity, protective cover, and carbon sequestration, and off-site benefits from more productive use of labor, reduced pressure on protected areas, and the introduction of rare and threatened medicinal species onto private farmland.

KEY WORDS: bamboo, community decision making, Himalaya, India, integrated natural resource management, land rehabilitation, medicinal plants, reforestation, village.

Published: December 20, 2001

\section{INTRODUCTION}

The Himalaya is a vast mountain system extending into eight developing countries in South Asia: Afghanistan, Bangladesh, Bhutan, China, India, Myanmar, Nepal, and Pakistan. The fact that India is recognized as a megadiversity country and as one of the 10 most extensively forested areas in the world is due mainly to the Himalaya. Although it covers only $18 \%$ of India's geographical area, the Himalaya accounts for more than $50 \%$ of the country's forest cover and $40 \%$ of the species endemic to the Indian subcontinent. Losses of forest cover, biodiversity, agricultural productivity, and ecosystem services are interlinked problems in the region that threaten the sustainable livelihoods of not only $115 \times 10^{6}$ mountain people but also the much larger population inhabiting the adjoining Indo-gangetic plains (Hamilton 1987, Ives and Messerli 1989, Myers 1990, Hurni 1999).

Until the 1970s, environmental conservation, food security, and rural economic advances were treated as largely independent sectors of research and development. The poor outcomes of sector-oriented approaches catalyzed efforts to address environmental and socioeconomic problems concurrently. Such approaches, commonly referred to as integrated natural resource research or management or development, essentially meant the integration of 
ecological and socioeconomic research, of traditional and conventional science, and of different actors and stakeholders. Multiple scales of environmental and economic development imperatives, from long to short term and from local to global, need to be considered in this type of undertaking. Although knowledge about the principles and potential advantages of integrated approaches has increased in recent years (Holling and Meffe 1996, Jenssen and Goldsworthy 1996, Antunes and Santos 1999, Bellamy and Johnson 2000, Lunde and Iremonger 2000), there are scientific, technological, and institutional limitations when it comes to putting the theory into practice (Thapa and Weber 1995, Maikhuri et al. 2000).

The identification of "key" natural resource management interventions, analogous to the concept of keystone species discussed by Paine (1969) and Walker (1991), that would make it possible to address environmental and socioeconomic problems simultaneously is an important dimension of integrated management. About $40 \%$ of the Indian Himalaya is degraded land. Rehabilitation will be a key intervention if it enables local communities to regenerate and/or conserve natural resources while at the same time aiding their social development. The benefits to vegetation recovery, the hydrological balance, and soil conservation that would be gained by rehabilitating such a vast area would also help the global community by reducing the frequency and intensity of flood damage in the downstream Indo-gangetic plains and improving biodiversity conservation and carbon sequestration.

Since the 1970 s there have been huge investments in establishing tree plantations on degraded lands, but the outcomes have been poor, largely because the project designs did not address the needs of local residents (Blaikie 1989, Chambers et al. 1989, Doolette and Magrath 1990). Villagers deliberately damaged plantations for several reasons. First, the species chosen for planting were conifers, rather than the multipurpose broadleaved species that could meet the essential needs of the local people. Although conifer timber could be a source of income to local residents, India's national forest policy does not allow it to be harvested commercially because of the ecological damage that harvesting causes on steep slopes. As a result, the villagers perceived the establishment of conifer plantations as a commitment to enhancing global environmental benefits at the expense of their own socioeconomic development. Second, the only involvement that local people had in these plantation projects was as part of the labor force. They did receive some benefits from this in the form of wages, but it was made clear that they were hired only because that was cheaper than importing workers from outside. Finally, local residents frequently set fires in the plantations to improve the grass forage that is so important for traditional livestock husbandry. The mortality of planted saplings caused by these fires led to replanting, which meant more wages for the villagers. Another problem was the fact that the saplings, which were raised in centralized nurseries and transported long distances to the plantations, were often damaged by the time they were planted. The absence of treatments to ameliorate nutrient and water stresses also contributed to the failure of these plantations (Saxena et al. 1993, Rao and Saxena 1994).

A major challenge is to develop rehabilitation strategies that address both economic and environmental concerns across spatial (local/global) and temporal (short-term/long-term) scales. This paper describes a case study in a high-altitude Himalayan village where this challenge was met by identifying rehabilitation technologies based on indigenous knowledge and by involving the villagers directly in the design, implementation, and monitoring of the project.

\section{SOCIO-ECOLOGICAL SETTING OF THE STUDY AREA}

The study was carried out in Khaljhuni village (Table 1), which is on the margin of the Nanda Devi Biosphere Reserve in the Indian central Himalaya. It is typical of the 4175 villages located close to the alpine zone. All these villages are characterized by relatively high inaccessibility, small populations, a subsistence economy based on crop-livestock mixed farming and nontimber forest products, homogeneity of resource use by different sociocultural-economic groups, and strong traditions of social integration (Farooquee and Saxena 1996, Rao and Saxena 1996). The Khaljhuni village community comprises two indigenous ethnic groups: the Bhotiya tribe and nontribals. Forty-three percent of land holdings are $>2$ ha, $42 \%$ are $0.2-2$ ha, and $15 \%$ are $<0.2$ ha. Smallholders provide labor for large landholders and receive food grains as payment. At the village level, food production is sufficient to meet local subsistence needs.

Table 1. Ecological and socioeconomic features of the Khaljhuni village, Almora district, India (values in parentheses are the percentage of the total in a given category).

\begin{tabular}{lc}
\hline \hline Feature & Value \\
\hline Number of households & 29 \\
Population & \\
$\quad$ Bhotiya tribe & 194 \\
$\quad$ Nontribals & 26 \\
$\quad$ Total & 220 \\
Elevation (m above sea level) & $2200-2500$ \\
Aspect & East-facing \\
Slope $\left({ }^{\circ}\right)$ & $35-45$ \\
Annual rainfall (cm) & 110 \\
Mean monthly maximum temperature $\left({ }^{\circ} \mathrm{C}\right)$ & $8.5-24.2$ \\
Mean monthly minimum temperature $\left({ }^{\circ} \mathrm{C}\right)$ & $1.8-16.1$ \\
Soil depth (cm) & $20-100$ \\
Land use (ha) & \\
Agriculture & $68.0(13.5)$ \\
Community/Panchayat forests & $301.9(59.9)$ \\
Civil forests & $134.3(26.6)$ \\
$\quad$ Total geographical area & $504.2(100.00)$ \\
Livestock & \\
Bullocks and cows & $241(31.9)$ \\
Sheep and goats & $515(68.1)$ \\
Total & $756(100.00)$ \\
\hline
\end{tabular}

The village landscape is divided into three elements: rain-fed agriculture, village community forests, and civil 
forests. Forest leaf litter mixed with livestock excreta is applied as manure in crop fields. Three crops are harvested over a period of $2 \mathrm{yr}$ near homesteads, and one crop every 4-6 yr in distant farm fields. Amaranthus paniculatus, Hordeum vulgare, $H$. himalyense, and Fagopyrum esculentum are the major crops. Government reserve forests and alpine meadows surround the village. Village community and reserve forests are dense ( $>80 \%$ crown cover and $80-140 \mathrm{~m}^{2} /$ ha basal area). Civil forests are highly degraded (crown cover $<10 \%$ and $0.4-5 \mathrm{~m}^{2} /$ ha basal area).

Except for the core zone of the biosphere reserve, the local people have been granted rights of utilization for nontimber forest products. The forest council, which consists of seven individuals elected by the people and one government official, is empowered to make decisions about how the resources of the community forests are used and the government forest department has authority over the reserve and civil forests. Resource use rights in the core zone, an area far from the village, were terminated in 1988. Until that time, the villagers would camp there during the summer to graze livestock, collect medicinal and wild edible plants, and harvest temperate bamboo (Thamnocalamus spathiflorus), which is used to make traditional handicrafts, from the reserve forests between the village and the core zone. When customary rights in the core zone were terminated, the inhabitants used the areas near the village much more intensively, resulting in extreme degradation of the civil forest land (Rao and Saxena 1994).

\section{THE PRESENT APPROACH}

The rehabilitation strategy comprised the following steps: (1) conducting a survey of local perceptions and indigenous knowledge related to the rehabilitation of degraded forest land, (2) analyzing the villagers' perceptions from the perspectives of other stakeholders and their concerns, (3) discussing these perceptions with the villagers and identifying possible rehabitation methods based on scientific knowledge, and (4) facilitating consensus with regard to the framework, implementation, and monitoring of the rehabilitation project.

\section{People's perceptions}

Seventy adults, including at least one male and one female from each household, were interviewed. We explained our intention to conduct a rehabilitation trial based on indigenous knowledge and designed to address local needs and preferences, and then sought responses to these questions:

- What were his/her preferences with regard to land rehabilitation, and what were the reasons for those preferences?

- What contributions could s/he make to rehabilitation?

Most people responsed to the first question by saying that they would prefer to plant temperate bamboo (Thamnocalamus spathiflorus); the second choice was the cultivation of medicinal plants (Table 2). These species were chosen because of their significant contributions to the rural economy and the restrictions on their extraction from the wild imposed by conservation policies. Only $8 \%$ of the respondents suggested planting trees. It was clear that the local residents were more interested in the immediate tangible benefits they could obtain from rehabilitation than in the long-term tangible and intangible benefits (e.g., soil conservation, hydrological balance, carbon sequestration, and biodiversity conservation) that were the primary national and global concerns. They were, however, aware of all these benefits except for carbon sequestration. All the respondents suggested the application of a basal dose of manure and protection from grazing as prerequisites to successful rehabilitation.

The fact that all the villagers considered it important to involve the whole community in decision making suggested that they had lost faith in the forest council. The council was unpopular because: (1) it made decisions without consulting the community, (2) council members tended to use their power and position to advance their own interests rather than for the benefit of the community, (3) it had used grants improperly, and (4) most council members had a poor understanding of appropriate rehabilitation technologies. Even though we assured the villagers that all the tangible benefits from rehabilitation would accrue to the community, they would not agree to provide voluntary labor. Instead, they insisted on securing grants for payment of wages as had occurred during previous projects. However, they did agree to contribute to the project by providing social fencing, which would enable traditional regulatory mechanisms to protect the treated area from grazing and fire, and by supplying farmyard manure and seeds, seedlings, and saplings from the community forests. All the respondents suggested following traditional norms for sharing costs and benefits, implying an equal distribution between all households and the transfer of costs/benefits between households by mutual understanding.

Table 2. Results of a survey of villagers' preferences regarding the rehabilitation of degraded lands.

\begin{tabular}{lc}
\hline \hline Land use option & Respondents (\%) \\
\hline Treatments/inputs & 8 \\
Planting trees & 58 \\
Planting bamboo (Thamnocalamus spathiflorus) & \\
Cultivation of medicinal plants & 34 \\
Aconitum heterophyllum & 34 \\
Allium stracheyi & 34 \\
Angelica glauca & 34 \\
Carum carvi & 17 \\
Nardostachys grandiflora & 9 \\
Orachis latifolia & 34 \\
Picrorhiza kurrooa & 17 \\
Podophyllum hexandrum & 34 \\
Rheum australe & 9 \\
Saussurea lappa & 9 \\
Swertia chirayta & 34 \\
Tanacetum tomentosum & 17 \\
Thalictrum foliosum & 27 \\
Introduction of both bamboo and medicinal species & 100 \\
Protection from grazing & 100 \\
Soil management/organic manuring & \\
Decision making & \\
&
\end{tabular}


People's contribution

Voluntary labor

0

Farmyard manure

\section{Enhancement of people's perceptions and project implementation}

A review of the villagers' perceptions showed that they were unaware of or did not understand several important issues identified by the scientific literature and a rapid ecological survey of the area. In addition, they were not familiar with the biological peculiarities of $T$. spathiflorus, which is a gregarious, flowering plant that displays low productivity for 3-4 yr after flowering. Because bamboo flowering is unpredictable, planting this species alone would be a high-risk proposal.

T. spathiflorus and many medicinal species were already regenerating in shaded and moist microhabitats dominated by Quercus leucotrichophora, Aesculus indica, and Juglans regia. The bamboo and the medicinal species requested were thus likely to survive the continued canopy growth of these multipurpose broadleaved trees. Poor agronomic knowledge about these rare and threatened medicinal species (Jain and Sastry 1979) and uncertainties related to market demand and price mean that more species should be tested than just those that are the most profitable at present.

Because medicinal species are tender herbs, they require intensive weeding and soil management to succeed on degraded sites and could be cultivated more profitably in abandoned fields, which are more fertile. The production of propagules of these species should be the primary objective and income generation the secondary purpose of rehabilitation. At the time the project was implemented, bamboo could be planted only through vegetative means because its seeds were not available, whereas both seed and vegetative propagation options were possible for medicinal plants. Mortality in a stressed environment is less likely with vegetative propagation than with sexual reproduction.

Planting trees on degraded lands could result in micro-environmental changes that would facilitate the natural regeneration of medicinal plants and temperate bamboo. A shortfall in grass production for fodder as the tree canopy developed was expected, because most palatable grasses grow in open habitats. It would probably be possible to compensate for this shortfall using income from bamboo, medicinal plants, and tree products.

Continuous harvesting of bamboo, medicinal species, and grass fodder is likely to aggravate nutrient stress in a recovering site because all these species have surface root systems. Although trees with litter that decomposes quickly may not provide immediate tangible benefits, they would draw nutrients from deeper soils and enrich the surface soil. This in turn would enhance the productivity of the products preferred by the villagers. The nitrogenfixing trees Alnus nepalensis and Alnus nitida were more suitable for promoting the rapid recovery of soil fertility.

With the consent of forest council members, the above issues related to local perceptions and possibilities for development were discussed with the villagers at a meeting held on the same day as community cultural ceremonies to ensure that all families participated. This process made it easier to reach a consensus about undertaking the following interventions to rehabilitate an 8-ha plot of civil forest land:

- social fencing of the site;

- planting cuttings of $T$. spathiflorus and saplings of $A$. indica, Q. leucotrichophora, and J. regia collected from community forests at regular intervals of $1 \mathrm{~m}$ in pits measuring $40 \times 40 \times 40 \mathrm{~cm}$, and providing $500 \mathrm{~g}$ of farmyard manure for each pit;

- bench-terracing microsites with a soil depth $>30 \mathrm{~cm}$ and treating them with $18 \mathrm{t} / \mathrm{ha}$ of organic manure to facilitate the introduction of the medicinal species Aconitum heterophyllum, Allium stracheyi, Angelica glauca, Carum carvi, Picrorhiza kurrooa, Rheum australe, and Tanacetum tomentosum from the community forests;

- harvesting bamboo and grasses at the end of the growing season (October) according to traditional practices;

- lopping and thinning the trees only after they had reached a height of $5 \mathrm{~m}$; and

- employing only local people to meet labor needs and paying wages out of the project fund.

\section{MONITORING}

A complete census of planted species was undertaken after $7 \mathrm{yr}$ to assess survival rates. The heights of 50 random individuals of each species were measured. Ten individuals per species were harvested for biomass estimation. Three farmers started cultivating their own medicinal plants after working on the rehabilitation site; their fields were monitored to estimate harvestable yields, and the same yields were assumed for the rehabilitated site. All inputs and outputs were monitored, converted to their monetary equivalents based on buying and selling prices in the village, and adjusted to net present value (NPV) at a $12 \%$ discount rate. Three composite samples of surface soil ( $0-15 \mathrm{~cm}$ deep) taken before and after $7 \mathrm{yr}$ of rehabilitation were analyzed for $\mathrm{pH}$, organic carbon, total nitrogen, and water-holding capacity (Jackson 1962, Rao et al. 1999).

\section{On-site impacts}

Bamboo (Thamnocalamus spathiflorus) showed the highest survival rate and biomass, followed by Aesculus indica trees. Quercus leucotrichophora had a lower survival rate than Juglans regia, although there was no significant difference in their biomass accumulation (Table 3 ). Natural regeneration of woody species at the site was negligible.

Table 3. Survival and growth of tree and bamboo species at rehabilitated sites after $7 \mathrm{yr}$ (mean \pm standard error of mean). Height growth is expressed in centimeters and biomass in kilograms per plant.

\begin{tabular}{lcccccc}
\hline \hline & Survival & Height & \multicolumn{4}{c}{ Aboveground biomass } \\
\cline { 3 - 7 } Species & $(\%)$ & growth & Bole/main stems & Branches & Leaves & Total \\
\hline Aesculus indica & 60 & $260 \pm 17$ & $8.1 \pm 1.1$ & $2.6 \pm 0.3$ & $1.1 \pm 0.2$ & $11.8 \pm 1.2$ \\
Juglans regia & 23 & $140 \pm 13$ & $2.8 \pm 0.7$ & $1.1 \pm 0.3$ & $1.2 \pm 0.5$ & $5.1 \pm 1.0$
\end{tabular}




\begin{tabular}{lcccccc}
$\begin{array}{l}\text { Quercus } \\
\text { leucotrichophora }\end{array}$ & 9 & $160 \pm 11$ & $3.2 \pm 0.6$ & $0.8 \pm 0.1$ & $1.5 \pm 0.3$ & $5.5 \pm 0.5$ \\
$\begin{array}{c}\text { Thamnocalamus } \\
\text { spathiflorus }\end{array}$ & 72 & $260 \pm 4$ & $25.6 \pm 0.8$ & $8.1 \pm 0.5$ & $10.6 \pm 0.8$ & $44.3 \pm 1.8$ \\
\hline
\end{tabular}

Aconitum heterophyllum was the most profitable medicinal species, and Angelica glauca the least (Table 4). Natural regeneration of introduced medicinal species was observed, but not beyond the microsites at which they were introduced.

Table 4. Prices and yields of medicinal products from the cultivation of medicinal species in private fields for the third through the seventh year of the study. Values in parentheses are the monetary values in U.S. dollars of the product per hectare (mean \pm standard error of mean). Yield is expressed in kilograms per hectare, and price variations during the course of the study are given in U.S. dollars per kilogram.

\begin{tabular}{|c|c|c|c|c|c|c|c|c|c|c|c|}
\hline \multirow[b]{2}{*}{ Species } & \multirow{2}{*}{$\begin{array}{c}\text { Price } \\
\text { variation }\end{array}$} & \multicolumn{2}{|c|}{ Third year } & \multicolumn{2}{|c|}{ Fourth year } & \multicolumn{2}{|c|}{ Fifth year } & \multicolumn{2}{|c|}{ Sixth year } & \multicolumn{2}{|c|}{ Seventh year } \\
\hline & & Yield & Price & Yield & Price & Yield & Price & Yield & Price & Yield & Price \\
\hline Allium stracheyi & $0.4-0.6$ & $553 \pm 47$ & $247 \pm 21$ & $530 \pm 71$ & $251 \pm 34$ & $557 \pm 67$ & $264 \pm 32$ & $570 \pm 92$ & $368 \pm 48$ & $561 \pm 41$ & $325 \pm 24$ \\
\hline Angelica glauca & $0.4-0.6$ & $\ldots$ & $\ldots$ & $875 \pm 43$ & $391 \pm 19$ & $\ldots$ & $\ldots$ & $\ldots$ & $\ldots$ & $828 \pm 39$ & $436 \pm 21$ \\
\hline Carum carvi & $0.5-0.6$ & $370 \pm 40$ & $195 \pm 21$ & $440 \pm 41$ & $243 \pm 23$ & $484 \pm 37$ & $280 \pm 21$ & $437 \pm 57$ & $288 \pm 38$ & $464 \pm 37$ & $305 \pm 24$ \\
\hline Aconitum heteropyllum & $24-32$ & $\cdots$ & $\ldots$ & $270 \pm 34$ & $6400 \pm 805$ & $\ldots$ & $\cdots$ & $\cdots$ & $\cdots$ & $289 \pm 31$ & $9126 \pm 979$ \\
\hline Picrorhiza kurrooa & $2.2-2.7$ & $\ldots$ & $\ldots$ & $213 \pm 29$ & $476 \pm 65$ & $\ldots$ & $\ldots$ & $\ldots$ & $\ldots$ & $240 \pm 31$ & $663 \pm 86$ \\
\hline Rheum australe & $1-1.2$ & $\cdots$ & $\ldots$ & $638 \pm 29$ & $487 \pm 29$ & $\ldots$ & $\cdots$ & $597 \pm 63$ & $738 \pm 78$ & $\cdots$ & $\ldots$ \\
\hline Tanacetum tomentosum & $0.9-1.1$ & $827 \pm 69$ & $740 \pm 62$ & $776 \pm 85$ & $735 \pm 81$ & $801 \pm 74$ & $759 \pm 90$ & $784 \pm 81$ & $867 \pm 90$ & $780 \pm 80$ & $862 \pm 88$ \\
\hline
\end{tabular}

Labor was the only paid input. Direct benefits to the local people were available from grass fodder from the beginning of the project, from medicinal plants after the third year, and from bamboo after the fourth year. The NPV of total benefits over the 7-yr period exceeded that of total costs (Table 5).

Table 5. Monetary costs and benefits of land rehabilitation expressed in U.S. dollars per hectare (net present value at a discount rate of $12 \%$ ).

\begin{tabular}{lcccccccc}
\hline \hline Costs/benefits & Year 1 & Year 2 & Year 3 & Year 4 & Year 5 & Year 6 & Year 7 & Total \\
\hline Costs & & & & & & & & \\
$\quad$ Land preparation & 35 & $\ldots$ & $\ldots$ & $\ldots$ & $\ldots$ & $\ldots$ & $\ldots$ & 35 \\
$\quad$ Plantation & 141 & $\ldots$ & $\ldots$ & $\ldots$ & $\ldots$ & $\ldots$ & $\ldots$ & 141 \\
$\quad$ Maintenance & 73 & 13 & 12 & 9 & 8 & 7 & 7 & 129 \\
Total costs & 249 & 13 & 12 & 9 & 8 & 7 & 7 & 305 \\
Benefits & & & & & & & & \\
$\quad$ Fodder & 42 & 44 & 39 & 35 & 31 & 28 & 22 & 241 \\
$\quad$ Bamboo & $\ldots$ & $\ldots$ & $\ldots$ & 7 & 20 & 22 & 25 & 74 \\
$\quad$ Medicinal products & $\ldots$ & $\ldots$ & 6 & 8 & 2 & 3 & 10 & 29 \\
Total benefits & 42 & 44 & 45 & 50 & 53 & 53 & 57 & 344 \\
\hline
\end{tabular}

Soil organic carbon, nitrogen, and water-holding capacity improved significantly over the 7-yr period (Table 6). Rehabilitation also led to a higher level of carbon sequestration as a result of the buildup of soil organic matter and woody biomass (Table 7). The continuation of social fencing for the full $7 \mathrm{yr}$ was a good indicator that the villagers appreciated the benefits generated by the rehabilitation trial.

Table 6. Physical and chemical characteristics of the soil before and after seven years of rehabilitation (mean \pm standard error of mean).

\begin{tabular}{lcc}
\hline \hline Characteristic & Before rehabilitation & After rehabilitation \\
\hline $\mathrm{pH}$ & $5.8 \pm 0.02$ & $6.1 \pm 0.02$ \\
Water-holding capacity & $27.5 \pm 1.9$ & $35.6 \pm 1.6$ \\
Carbon (\%) & $1.7 \pm 0.3$ & $2.9 \pm 0.3$ \\
Nitrogen (\%) & $0.15 \pm 0.01$ & $0.21 \pm 0.04$ \\
\hline
\end{tabular}

Table 7. Carbon sequestration rate in soil and vegetation after $7 \mathrm{yr}$ of planting on rehabilitation sites expressed as tons per hectare per year.

\begin{tabular}{lc}
\hline \hline Characteristics & Carbon sequestration \\
\hline Soil $(0-15 \mathrm{~cm})$ & 3.4 \\
Tree bole/bamboo culm & 4.3 \\
Total & 7.7 \\
\hline
\end{tabular}


The availability of fodder, medicinal plants, and bamboo from the rehabilitated site close to their dwellings could save the villagers an average of 28 man- and 20 woman-days of labor per year, time they would otherwise have spent collecting plants from distant forests and alpine meadows. During discussions of the overall impact of the project, people commented that this saving of labor gave them more time for farming, handicrafts, and health care. It was also suggested that the availability of products from degraded lands reduced the pressure on government forests and pastures. The fact that local farmers (even if there were only three of them) took the initiative to cultivate medicinal plants on private farmland after the rehabilitation treatment could also be considered an off-site benefit.

\section{DISCUSSION}

For the successful rehabilitation of degraded lands in developing countries, local concerns about immediate tangible benefits must be integrated into global concerns about the environment. This can be accomplished by building on indigenous knowledge and traditions (Altieri and Masera 1993, DeWalt 1994) and by involving the whole village community in decision making. Communicating with villagers through the forest council is often unpopular, because this institution, which was imposed on the villages in the 1930s, has not been able to address their common needs and aspirations (Rao and Saxena 1996). The relatively small size of Himalayan villages and the high degree of similarity in resource use practices by the different socioeconomic and cultural groups within each village make it easier to reach a consensus on a rehabilitation approach. In the present study, the availability of medicinal plants, grass fodder, and bamboo from degraded lands provided direct economic benefits to the local people and also reduced the pressure on government forests and pastures. This made a significant contribution to Himalayan biodiversity and ecosystem services, which are a global concern.

Substantial environmental benefits accrue from planting trees on sloping lands, although the villagers initially showed little enthusiasm for this practice. However, after discussions designed to expand local perceptions, they accepted the planting of trees traditionally valued for nontimber products and also welcomed the income from shade-tolerant bamboo and medicinal species. People were reconciled to the shortfall in grass fodder production caused by the spreading shade of developing tree canopies by the income they obtained from medicinal plants and bamboo from the third year and the potential availability of tree fodder in the long term. Tree planting alone can succeed in situations where the scarcity of tree-based products threatens the livelihood of local communities and/or where policy provides for monetary benefits from commercial timber harvesting (Bartlett 1992, Fox 1993).

Although the present rehabilitation strategy appears costly (U.S. $\$ 305 /$ ha) when compared with conventional conifer plantation projects (U.S. $\$ 160-190 / \mathrm{ha})$, its ecological and socioeconomic benefits are significantly higher (Saxena et al. 1993, Maikhuri et al. 1997, Rao et al. 1999). It should be noted, however, that the cost of conventional reforestation projects assumes a single expenditure for planting. The real cost may be much higher, because replanting is often necessary due to low survival rates. Furthermore, in those projects, saplings are raised in centralized nurseries, and the costs of nursery establishment and transportation to plantation sites are not included in the reforestation budget. Although transplantation of saplings from microsites in forests where natural regeneration is profuse can save time and expenditures for nursery maintenance, this method may not be appropriate for all species, as can be seen in the high mortality of Quercus leucotrichophora in this trial.

The introduction of "nurse species" or "keystone species" may speed up recovery while lowering labor and manure inputs (Ramakrishnan et al. 1996, Andreas and Michaela 1999). However, such species are likely to be acceptable to local people only if they serve their needs. In the present case, nitrogen-fixing Alnus spp. could have helped the soil recover its fertility more quickly, but was rejected by the villagers because it yielded poor-quality fodder and fuelwood. The $Q$. leucotrichophora, Aesculus indica, and Juglans regia selected by the local residents did not prove to be "nurse species" in that they failed to facilitate natural vegetation regeneration over a period of $7 \mathrm{yr}$. Although these tree species were not capable of fixing nitrogen, they could significantly improve soil fertility as a result of their rapid nutrient cycling and soil and water conservation functions. Improving our knowledge about the ecological attributes of the species valued by local people could offer better options for species selection.

\section{CONCLUSION}

Rehabilitation in developing countries that serves both local and global interests will have to be promoted as a fully funded government or donor initiative because of the limited capacity of ordinary hill people. The strategies that address local needs are the ones most likely to secure local participation and provide opportunities for achieving higher returns at lower rehabilitation costs. In the absence of such approaches, it is quite likely that local residents will adopt land use practices that provide quick monetary returns at huge environmental and social costs (Sen et al. 1997, Nautiyal et al. 1998)

Supplementing indigenous knowledge and the involvement of the whole village community in decision making seem to be the key requirements all across the Himalaya for integrating and reconciling diverse concerns related to land rehabilitation. The wide range in biophysical and socioeconomic conditions in the Himalaya demands flexible and adaptable approaches to the identification of appropriate rehabilitation technologies. The introduction of medicinal plants and temperate bamboo as well as multipurpose broadleaved trees offers comparative advantages only in high-altitude villages close to the alpine zone. In mid- and low-altitude villages, we found that the best options for rehabilitation were the development of multipurpose tree-crop mixed farming, the recycling of run-off, and soil management (Maikhuri et al. 1997a,b). More research is necessary to expand our knowledge about participatory land rehabilitation as a key intervention for addressing multiple problems and diverse concerns related to natural resources.

\section{RESPONSES TO THIS ARTICLE}

Responses to this article are invited. If accepted for publication, your response will be hyperlinked to the article. To submit a comment, follow this link. To read comments already accepted, follow this link.

\section{Acknowledgments:}

We are grateful to the Director of the G. B. Pant Institute of Himalayan Environment and Development for the facilities, to the TSBF program for partial financial support, and to the two anonymous referees for their valuable suggestions and comments.

\section{LITERATURE CITED}

Altieri, M. A., and O. Masera. 1993. Sustainable rural development in Latin America: building from the bottom up. Ecological Economics 7:93-121. 
Andreas, S., and Z. Michaela. 1999. Plant species decline due to abandonment of meadows cannot easily be reversed by mowing: a case study from the Alps. Journal of Vegetation Science 10:151-164.

Antunes, P., and R. Santos. 1999. Integrated environmental management of the oceans. Ecological Economics 31:215-226.

Bartlett, A. G. 1992. A review of community forestry advances in Nepal. Commonwealth Forestry Review 71 : 95-100.

Bellamy, J. A., and A. K. L. Johnson. 2000. Integrated resource management: moving from rhetoric to practice in Australian agriculture. Environmental Management 25:265-280.

Blaikie, P. 1989. Explanation and policy in land degradation and rehabilitation for developing countries. Land Degradation and Rehabilitation 1:23-37.

Chambers, R., N. C. Saxena, and R. Shah. 1989. To the hands of the poor: water and trees. Oxford and IBH, New Delhi, India.

Dewalt, B. R. 1994. Using indigenous knowledge to improve agriculture and natural resource management. Human Organizations 5:123-131.

Doolette, J. B., and W. B. Magrath, editors. 1990. Watershed development in Asia: strategies and technologies. World Bank Technical Paper Number 127. World Bank, Washington, D.C., USA.

Farooquee, N. A., and K. G. Saxena. 1996. Conservation and utilization of medicinal plants in high hills of the central Himalaya. Environmental Conservation 23:75-80.

Fox, J. 1993. Forest resources in a Nepali village in 1980 and 1990: the positive influence of population growth. Mountain Research and Development 13: 89-98.

Hamilton, L. S. 1987. What are the impacts of Himalayan deforestation on Ganges-Brahmaputra lowlands and delta? Mountain Research and Development 7: 256-263.

Holling, C. S., and G. K. Meffe. 1996. Command and control and the pathology of natural resource management. Conservation Biology 10:328-337.

Hurni, H. 1999. Sustainable management of natural resources in African and Asian mountains. Ambio 28:382-389.

Ives, J. D., and B. Messerli. 1989. The Himalayan dilemma: reconciling environment and development. Routledge, London, UK.

Jackson, M. L. 1962. Soil chemical analysis. Blackwell, Oxford, UK.

Jenssen, W., and P. Goldsworthy. 1996. Multidisiplinary research for natural resource management: conceptual and practical implications. Agricultural Systems 51:259-279.

Jain, S. K., and A. R. K. Sastry. 1979. Threatened plants of India. Botanical Survey of India, Howrah, India.

Lunde, H. G., and S. Iremonger. 2000. Omissions, commissions and decisions: the need for integrated resource assessments. Forest Ecology and Management 128:3-10.

Maikhuri, R. K., S. Nautiyal, K. S. Rao, K. Chandrasekhar, R. Gavali, and K. G. Saxena. 2000. Analysis and resolution of protected area-people conflicts in Nanda Devi Biosphere Reserve. Environmental Conservation 27:43-53.

Maikhuri, R. K., R. L. Semwal, K. S. Rao, and K. G. Saxena. 1997a. Agroforestry for rehabilitation of degraded community lands: a case study in Garhwal Himalaya. International Tree Crops Journal 9:89-99.

Maikhuri, R. K., R. L. Semwal, K. S. Rao, and K. G. Saxena. 1997b. Rehabilitation of degraded community lands for sustainable development in Himalaya: a case study in Garhwal Himalaya. International Journal of Sustainable Development and World Ecology 4:192-203.

Myers, N. 1990. The biodiversity challenge: expanded hot-spots analysis. Environmentalist 10:243-256.

Nautiyal, S., R. K. Maikhuri, R. L. Semwal, K. S. Rao, and K. G. Saxena. 1998. Agroforestry systems in the rural landscape-a case study in Garhwal Himalaya, India. Agroforestry Systems 41:151-165.

Paine, R. T. 1969. A note on trophic complexity and community stability. American Naturalist 103:91-93.

Ramakrishnan, P. S., A. N. Purohit, K. G. Saxena, K. S. Rao, and R. K. Maikhuri, editors. 1996. Conservation and management of biological resources in Himalaya. Oxford and IBH, New Delhi, India.

Rao, K. S., and K. G. Saxena. 1994. Sustainable development and rehabilitation of degraded village lands in Himalaya. Himavikas Publication Number 8. Bishen Singh Mahendra Pal Singh, Dehradun, India.

Rao, K. S., and K. G. Saxena. 1996. Minor forest products' management: problems and prospects in high altitude villages of central Himalaya. International Journal of Sustainable Development and World Ecology 3:60-70.

Rao, K. S., R. K. Maikhuri, and K. G. Saxena. 1999. Participatory approach to rehabilitation of degraded forest lands: a case study in a high altitude village of Indian Himalaya. International Tree Crops Journal 10:1-17.

Saxena, K. G., K. S. Rao, and A. N. Purohit. 1993. Sustainable forestry-prospects in India. Journal of Sustainable Forestry 1:69-95.

Sen, K. K., K. S. Rao, and K. G. Saxena. 1997. Soil erosion due to settled upland farming in the Himalaya: a case study in Pranmati Watershed. International Journal of Sustainable Development and World Ecology 4:65-74.

Thapa, G. B., and K. E. Weber. 1995. Status and management of watersheds in the Upper Pokhara valley, Nepal. Environmental Management 19:497-513.

Walker, B. H. 1991. Biodiversity and ecological redundancy. Conservation Biology 6:18-23.

Address of Correspondent:

K. G. Saxena

School of Environmental Sciences

Jawaharlal Nehru University 
New Delhi, India 110067

Phone: +91-11-6172438

kgsaxena@jnuniv.ernet.in

Home | Archives | About | Login | Submissions | Notify | Contact | Search 